Volume 2

Number 2 Teaching Secrecy

January 2021

\title{
Classified: Secrecy and the State in Modern Britain
}

Diana Clark Gill

Independent Researcher, dkcgill@gmail.com

Follow this and additional works at: https://scholarworks.sjsu.edu/secrecyandsociety

Part of the Defense and Security Studies Commons, Journalism Studies Commons, and the Other International and Area Studies Commons

\section{Recommended Citation}

Gill, Diana Clark. 2021. "Classified: Secrecy and the State in Modern Britain." Secrecy and Society 2(2). https://doi.org/10.31979/2377-6188.2021.020212

https://scholarworks.sjsu.edu/secrecyandsociety/vol2/iss2/12

This Book Review is brought to you for free and open access by the School of Information at SJSU ScholarWorks. It has been accepted for inclusion in Secrecy and Society by an authorized administrator of SJSU ScholarWorks. For more information, please contact scholarworks@sjsu.edu.

\section{(c) (1)}

This work is licensed under a Creative Commons Attribution 4.0 License. 


\section{Classified: Secrecy and the State in Modern Britain}

\section{Keywords}

Britain, D-Notice system, freedom of information, government secrecy, Official Secrets Act, security classification of information, UK security services 
Review, Classified: Secrecy and the State in Modern Britain by Christopher Moran

\author{
Reviewed by Diana Clark Gill
}

Classified: Secrecy and the State in Modern Britain, Cambridge: Cambridge University Press, 2013. 449 pp. / ISBN 1107000998 /

https://doi.org/10.1017/CBO9780511734298

Authors have a difficult task when writing introductions to their books. In summarizing their topic, they sometimes raise not-to-be-realized expectations as to what their book will encompass. In reading the introduction to Classified: Secrecy and the State in Modern Britain, I found Christopher Moran's general discussion of government secrecy a tantalizing mix of WikiLeaks, British tendencies toward concealment, Fleet Street derring-do, narcissistic politicians, and the Official Secrets Act of Great Britain, originally passed in 1889 and revised in 1911. All this led me to hope that the book would be a treatise on state secrets prefaced by exploring the psychology behind English historian Peter Hennessy's quote that Moran (2013) includes on the British character -

...secrecy is as much a part of the English landscapes as the Cotswolds. It goes with the grain of our society. Its curtailment, not its continuity, would be aberrational. Whitehall...is only its greatest, not its sole monument. (11) 
A provocative quote to be sure, but one that Moran, an associate professor of US national security at the University of Warwick, never analyzes. Neither this quote, nor the similar sentiment Moran (2013) uses of a Labour Party leader who described secrecy as the "the real English disease and in particular the chronic ailment of the British Government" (13). Both quotes leave one wondering if the British are indeed more secretive than other nationalities, and if so why? Writer Anthony Sampson, who wrote Anatomy of Britain in 1963, theorized that mystery is how Brits contain authority or influence, magnifying it by its unspokenness.

"Secrecy," explains Anthony Sampson, "is one of the British obsessions, like class, which seems to express a deeper psychological need, as if it were a substitute for the mystery of a religion. Power in Britain originated in secrecy, as in America it thrived on publicity" (as cited in Winder 1986). ${ }^{1}$ An intriguing explanation, but Moran's assessment as an intelligence scholar would likely have added to it. The why of British secrecy would also have been a fitting complement to the "who, what, when, where and how" of Moran's actual thesis of journalism's growing combativeness over the control of information with the class-conscious, upper echelons of British intelligence in the $20^{\text {th }}$ century.

1 Sampson's quote could not be verified in his 1965 Anatomy of Britain Today (New York: Harper \& Row) or the 1971 New Anatomy of Britain (Hodder and Stoughton, UK). 
The missing fifth $\mathrm{W}$ aside, I did find Classified to be a fascinating peek behind the curtain at Whitehall. It does not, though, paint $20^{\text {th }}$ century British politicians very favorably. Moran (2013) contends that the revised Official Secrets Act (OSA) of 1911 made it illegal for anyone who worked for the British government to "collect, communicate or publish" any information that could prove "prejudicial to the...interests of the state" (23). This law would, over the years, enjoy extremely wide latitude. Offenders eventually included everyone from a part-time clerk in the Home Office who discussed bathroom supplies with his spouse to a British national who handed over British naval plans to the Nazis.

Suggestively, Moran theorizes that the Act was less about keeping military secrets out of enemy hands than about controlling the "loose lips" of the lower-classes who were, at the time, invading the civil services. Not of the gentry-class, such workers were considered untrustworthy of keeping government secrets; whether those of diplomatic treaties or the personal peccadilloes of cabinet ministers. Essentially, then, the OSA served as a control mechanism of "indoctrinate[ing] civil servants into the culture of closed government" (Moran 2013, 9). Examples of what the UK's "closed government" (Moran 2013, 9) withheld from the public included not disclosing its creation of intelligence services. Hidden were agencies such as MI5 (Military Intelligence, Section 5), SIS (Secret Intelligence Service, now known as MI6), and GCHQ (Government Communications Headquarters). 
In addition to controlling lower-class civil servants, political leaders were also seeing to their horror the "emergence of an inquisitive popular press" (Moran 2013, 25). The government tried controlling these reporters, whose activities were outside the Official Secrets Act, by issuing D-Notices, which indicated government disapproval of proposed newspaper articles. Though technically voluntary, reporters were nevertheless expected to abide by these notices and censor themselves accordingly. Or as Moran (2013) puts it, it was the attempt by British leaders to "graft honorable secrecy onto their social peers in journalism" (52).

Ironically, serious $20^{\text {th }}$ century breaches of British official secrets were committed by neither journalists nor middle-class clerical staff from the Home Office. Writing one's memoirs became all the rage following both world wars and it was the historical lions of history, such as former Prime Ministers Winston Churchill, David Lloyd George, former Foreign Secretary Anthony Eden, and Parliament member Richard Crossman, who felt that the Official Secrets Act did not apply to them. Entitled by privilege, they carted off official documents by the truckload and freely confessed former confidences to the reading public. It was these gentrified former leaders who the British government never quite figured out how to censor.

Traditional D-Notices ended in the D-Notice Affair of 1967 when a reporter Chapman Pincher revealed that British private cables and telegrams were being routinely scanned by security authorities. Prime Minister Harold 
Wilson cried foul, claiming that Pincher's paper had ignored two D-notices not to publish the story. This was a claim that the Daily Express denied. An inquiry was begun with the Privy Counselors who ruled in favor of the Daily Express. Prime Minister Wilson refused to accept the ruling and his public fury over the incident alerted the public, for the first time, of the D-Notice system in regulating what they were able to read in the daily newspaper (Greenslade 2015).

The Guardian reporter Roy Greenslade (2015) captured the aftermath. He explained in an article entitled The D-Notice System: A Typically British Fudge that Has Survived a Century that the D-Notice system was later redesigned becoming instead "standing D-Notices" and later still "defence advisory" (DA) notices. These notices had little legal status and were broad guidance decrees as what not to publish. But when the Guardian printed the Snowden leaks in 2013, without going through the office of the DA-Notice secretary, another revision of the system was triggered, transforming them into Defence and Security Media Advisory (DSMA) notices. DSMAs, like their predecessors, are voluntary, but can, according to the UK's DSMA website, result in legal action against violators who either fail to use the DSMA system to vet their articles, or are planning to publish information of a dangerously consequential nature.

A little over two decades after the D-Notice Affair, the UK Official Secrets Act was also rewritten to better adjust to modern conditions. Moran 
explains how memoirs were simultaneously discouraged by the secret services, who were releasing their own impressive-looking "official histories" to the reading public. Additionally, archives were opened up, allowing academics to quote more accurately about historical events. Transparency "appeared" to become the watchword of government secrets following the fall of the USSR. And in January of 2005, Britain enacted the Freedom of Information Act allowing a right of access to government information. In researching this book, Moran used original government documents relating to press censorship that had been declassified due to these very developments.

Structurally, the book is divided into four sections. The first establishes the beginning of the Official Secrets Act, traced back to 1889, and later revised in 1911 to prevent the dissemination of classified British information both internationally and domestically. Here Moran introduces the early $20^{\text {th }}$ century pressures that were mounting against Whitehall's attempt to control leakage of official secrets by both journalists and politicians eager to vindicate or glorify themselves in print.

He then uses the next two sections - Secrecy of the Press and Secrecy and Political Memoires - to drill down even further into these literary efforts of domestic actors railing against publishing restrictions. Finally, his last section, entitled Intelligence Secrets, Spy Memoires and Official Histories provides the meat of the book as Moran details how Whitehall finally 
conceded, after the war, that not only were certain secrets, such as the Bletchley Park code-breaking machines, going to come to light due to garrulous memoirists, but that the government itself might benefit from disclosing once classified material. For example, to establish a British counterpoint to the American narrative of having won the war single-handed.

This realization led to the British Government's momentous release of official histories which according to Moran (2013), "gives the secret state a voice in a crowded marketplace of press accounts, populist histories and memoirs" (326). It would also, according to Sir Dick White (the only person to head both the Security Service and the Secret Intelligence Service), "help de-sensationalize the current concept of intelligence and...correct...distorted and damaging private histories" (Moran 2013, 318).

While the repetition of cases involving violations of official secrets gets a little tiresome toward the end of the book, Moran does explore new ground in the tension between government censors and a free press needed by an informed public. Similar books, focused on the larger issue of official secrecy and attempts at censorship, include Kaeten Mistry and Hannah Gurman's edited Whistleblowing Nation: The History of National Security Disclosures and the Cult of State Secrecy and Michael Colaresi's book, Democracy Declassified: The Secrecy Dilemma in National Security. In comparison to Whistleblower, Moran's book is more finely focused on the role of journalism in resisting government secrecy, while Classified also benefits from having a 
less academic perspective than Colaresi's book, which allows it to better capture the non-scholarly reader's imagination.

Additionally, Moran's coverage is exhaustive, but even-handed when pushing for a more open government. Conceding the need for secrecy when confronting true enemies of the state, he makes the point that where "British governments failed was in thinking only in absolutes. For too long...officials clung to the belief that was no middle ground between total secrecy and total disclosure" (Moran 2013, 15). Classified details how the secrets of Her Majesty's Government went from never being revealed to having expiration dates.

Classified's greatest strength, however, is being rooted in its time period; allowing, as it does, the reader a delicious if disillusioning glimpse into the increasingly alien $20^{\text {th }}$ century as experienced in Great Britain. A post-Victorian era of conservative British values, of petty weaknesses of leaders willing to risk state security in order to vindicate themselves to posterity, of abysmally-lax security measures for state documents, and of the deep, abiding inquisitiveness of the British press. But, more than all that Classified is a book about fear - fear stemming as much from deeplyentrenched class divisions as it does from losing control of government secrets. Class divisions created the Official Secrets Act in response to the distrust and dread of the lesser social "other" - an opponent who was apparently no less viewed with suspicion than a declared foreign enemy of 
the British Isles - a subject, perhaps, even more interesting than that of the missing fifth $\mathrm{W}$.

\section{References}

Defence and Security Media Advisory Committee. 2020. The DSMA Notice System. https://dsma.uk/

Greenslade, Roy. 2015. "The D-notice System: A Typically British Fudge that Has Survived a Century." The Guardian, July 13. https://www.theguardian.com/media/2015/jul/31/d-notice-systemstate-media-press-freedom

Moran, Christopher. 2013. Classified: Secrecy and the State in Modern Britain. Cambridge: Cambridge University Press.

Winder, David. 1986. "Little Known British Tradition - Secrecy." The Christian Science Monitor, December 17. https://www.csmonitor.com/1986/1217/zwind.html 